\title{
PENGARUH SUKU BUNGA ACUAN BI, NILAI TUKAR RUPIAH DAN INFLASI TERHADAP NON-PERFORMING LOAN SEKTOR USAHA YANG DIBIAYAI BANK UMUM KONVENSIONAL DI INDONESIA
}

\author{
Andy Sucipto \\ Program Studi Magister Manajemen Universitas Tarumanagara \\ andy.sucipto84@gmail.com \\ Carunia Mulya Firdausy \\ Program Studi Magister Manajemen Universitas Tarumanagara \\ Masuk : 04-12-2020, revisi : 15-12-2020, diterima untuk diterbitkan : 16-12-2020
}

\begin{abstract}
The purpose of this study was to determine the effect of interest rate, exchange rate, and inflation on the Non-Performing Loans of manufacturing sectors that were financed by Conventional Commercial Banks in Indonesia. The sample used in this study consisted of 8 business sectors, namely mining, manufacturing, wholesale and retail trade, accommodation, transportation \& warehousing, finance, property, electricity, gas, and water. This study used a panel data regression analysis method with a random effect model (REM) approach. The results showed that the interest rate and inflation had no significant effects on the NPL of the manufacturing sector understudied, while the exchange rate had a significant effect on the NPL. However, the coefficient of determination was found to be 36.11 percent. This indicates that other variables affect the NPL of manufacturing sectors financed by the conventional bank in Indonesia.
\end{abstract}

Keywords: NPL, Interest Rate, Exchange Rate, Inflation

Abstrak: Tujuan penelitian ini adalah untuk mengetahui pengaruh suku bunga, nilai tukar dan inflasi terhadap Non-Performing Loan sektor manufaktur yang dibiayai oleh Bank Umum Konvensional di Indonesia. Sampel yang digunakan dalam penelitian ini terdiri dari 8 sektor usaha yaitu pertambangan, manufaktur, perdagangan grosir dan eceran, akomodasi, transportasi \& pergudangan, keuangan, properti, listrik, gas dan air. Penelitian ini menggunakan metode analisis regresi data panel dengan pendekatan random effect model (REM). Hasil penelitian menunjukkan bahwa suku bunga dan inflasi tidak berpengaruh signifikan terhadap NPL sektor manufaktur yang diteliti, sedangkan nilai tukar berpengaruh signifikan terhadap NPL. Namun, koefisien determinasi diperoleh sebesar 36,11 persen. Hal ini menunjukkan bahwa terdapat variabel lain yang mempengaruhi NPL sektor manufaktur yang dibiayai oleh bank konvensional di Indonesia.

Kata Kunci: NPL, Suku Bunga Acuan BI, Nilai Tukar, Inflasi

\section{PENDAHULUAN}

Bank merupakan salah satu institusi keuangan yang memegang peranan penting dalam perekonomian suatu negara. Hal ini karena kegiatan utama bank adalah menghimpun dana masyarakat dalam bentuk simpanan dan menyalurkannya kembali dalam bentuk kredit kepada pihak yang membutuhkan. Sehingga dapat dikatakan bahwa bisnis kredit merupakan bisnis utama perbankan dan menjadi salah satu bisnis dengan perkembangan yang cukup pesat di Indonesia. Peningkatan kredit tersebut dipengaruhi oleh aktivitas perekonomian tanah air. Dimana aktivitas ini juga dipengaruhi oleh kondisi makroekonomi suatu negara, seperti: pertumbuhan GDP, tingkat suku bunga, nilai tukar mata uang dan inflasi. Apabila kondisi makroekonomi tidak stabil maka kegiatan kredit pun akan ikut terganggu, yang pada akhirnya 
dapat menyebabkan pelaku usaha mengalami kesulitan dalam memenuhi kewajibannya ke Bank.

Ini menunjukkan bahwa penyaluran kredit juga memiliki risiko, yang timbul ketika debitur tidak mampu memenuhi kewajibannya sesuai perjanjian yang disepakati dengan pihak kreditur. Semakin besar kredit yang diberikan, maka akan diikuti juga tingginya risiko gagal bayar kredit oleh debitur. Risiko tersebut tercermin pada tingkat Non-Performing Loan (NPL).

Non-Performing Loan (NPL) masih menjadi masalah yang menakutkan dalam industri perbankan karena berpotensi menggerus keuntungan bank (Yudistira, 2016). Namun perkembangan NPL masih cenderung mengalami peningkatan seiring dengan meningkatnya pertumbuhan kredit yang diiringi ketidakstabilan makroekonomi (Apriyani, 2015). Diperkirakan penyebabnya terkait dengan suku bunga acuan BI, nilai tukar rupiah terhadap dolar Amerika dan inflasi. Oleh karena itu, penelitian ini ditujukan untuk mengetahui apakah ketiga faktor tersebut yang memengaruhi Non-Performing Loan dari sektor usaha manufaktur yang sumber dananya dibiayai perbankan konvensional.

\section{Tujuan Penelitian}

Tujuan dari penelitian ini adalah untuk:

1. Mengetahui pengaruh suku bunga acuan BI terhadap NPL sektor usaha yang dibiayai Bank Umum Konvensional di Indonesia.

2. Mengetahui pengaruh nilai tukar rupiah terhadap NPL sektor usaha yang dibiayai Bank Umum Konvensional di Indonesia.

3. Mengetahui pengaruh inflasi terhadap NPL sektor usaha yang dibiayai Bank Umum Konvensional di Indonesia.

4. Mengetahui pengaruh suku bunga acuan BI, nilai tukar rupiah, dan inflasi secara bersama-sama terhadap NPL sektor usaha yang dibiayai Bank Umum Konvensional di Indonesia.

\section{TINJAUAN PUSTAKA}

\section{Pengaruh Suku Bunga Acuan BI terhadap NPL}

Suku Bunga Acuan BI didefinisikan sebagai suku bunga kebijakan yang ditetapkan oleh Bank Indonesia yang mencerminkan sikap atau stance kebijakan moneter. Kebijakan ini akan diterapkan pada operasi moneter yang dilakukan Bank Indonesia melalui pengelolaan likuiditas (liquidity management) di pasar uang dengan tujuan mencapai target operasional kebijakan moneter. Target operasional dari suku bunga acuan BI adalah suku bunga Pasar Uang Antar Bank Overnight (PUAB O/N) yang kemudian akan diikuti dengan suku bunga simpanan dan pada akhirnya berpengaruh pada suku bunga kredit perbankan. Dengan mempertimbangkan faktor-faktor lain yang mempengaruhi perekonomian, Bank Indonesia umumnya akan meningkatkan suku bunga acuannya jika inflasi diperkirakan di atas target yang telah ditentukan, namun Bank Indonesia akan menurunkan suku bunga acuannya jika inflasi diperkirakan masih berada di bawah target yang ditentukan.

\section{Pengaruh nilai tukar rupiah terhadap NPL}

Nilai tukar adalah harga mata uang satu negara dalam satuan mata uang lainnya yang biasa disebut dengan reference currency (Shapiro, 2016). Wikutama (2010) menjelaskan bahwa melemahnya nilai mata uang home currency memberikan dampak buruk terhadap debitur yang memiliki eksposur kredit dalam mata uang asing, karena nilai pinjamannya akan mengalami peningkatan secara relatif akibat dari pelemahan nilai tukarnya. Peningkatan nilai pinjaman tersebut akan mengakibatkan penurunan pada kemampuan membayar debitur, yang pada akhirnya menyebabkan debitur mengalami gagal bayar, sehingga NPL berpotensi meningkat.

\section{Pengaruh inflasi terhadap NPL}

Inflasi adalah kondisi kenaikan tingkat harga yang terjadi secara terus-menerus, sehingga mempengaruhi individu, pengusaha, dan pemerintah (Miskhin, 2008). Saat terjadi cost push 
inflation, biaya bahan baku dan tenaga kerja biasanya naik sehingga menyebabkan biaya produksi ikut meningkat. Hal ini akan mengakibatkan terjadinya kenaikan harga barang yang dijual oleh produsen. Dengan adanya kenaikan harga jual, maka masyarakat akan merespon dengan cara mengurangi konsumsi mereka. Sehingga penjualan produsen akan mengalami penurunan diikuti dengan penurunan tingkat keuntungan, maka produsen sebagai debitur akan mengalami kesulitan dalam mengembalikan kredit, sehingga risiko terjadinya NPL akan meningkat. Sedangkan jika dilihat dari sisi demand pull inflation, dimana inflasi terjadi karena adanya permintaan yang tinggi pada suatu barang, sementara ketersediaan barang tersebut sangat terbatas, sehingga menyebabkan terjadinya kenaikan harga barang tersebut. Dengan pendapatan (income) yang tetap, maka kenaikan harga barang tersebut akan semakin membebani hidup masyarakat sehingga kemampuan dalam mengembalikan kredit akan menurun yang pada akhirnya menyebabkan risiko kredit meningkat.

\section{Gambar 1}

Kerangka Pemikiran

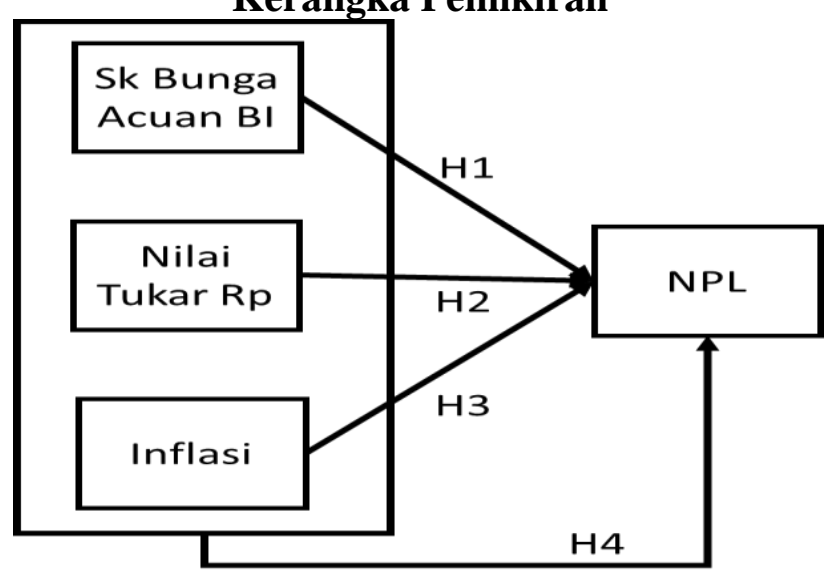

Hipotesis dalam penelitian ini adalah:

1. H1: Tingkat suku bunga acuan BI berpengaruh signifikan terhadap NPL sektor usaha yang dibiayai Bank Umum Konvensional di Indonesia.

2. H2: Nilai tukar rupiah terhadap USD berpengaruh signifikan terhadap NPL sektor usaha yang dibiayai Bank Umum Konvensional di Indonesia.

3. H3: Tingkat inflasi berpengaruh signifikan terhadap NPL sektor usaha yang dibiayai Bank Umum Konvensional di Indonesia.

4. H4: Suku bunga acuan BI, nilai tukar rupiah terhadap USD, dan inflasi secara simultan berpengaruh signifikan terhadap NPL sektor usaha yang dibiayai Bank Umum Konvensional di Indonesia.

\section{METODOLOGI PENELITIAN}

Jenis penelitian ini adalah jenis penelitian penjelasan (explanatory research) terkait pengaruh suku bunga acuan BI, nilai tukar rupiah dan inflasi terhadap non-performing loan sektor usaha yang didanai oleh bank umum konvensional di indonesia yang terdaftar dan diawasi oleh Otoritas Jasa Keuangan (OJK). Waktu atau periode penelitian dilakukan pada periode $2011-2019$.

Sumber data penelitian ini bersumber dari data sekunder Statistik Perbankan Indonesia (Otoritas Jasa Keuangan, 2020), Bank Indonesia (www.bi.go.id) dan Badan Pusat Statistik (www.bps.go.id). Data yang digunakan merupakan data panel yaitu gabungan antara data time series periode tahun 2011 hingga tahun 2019 dengan data cross section berupa sektor usaha yang dibiayai perbankan dengan jumlah observasi sebanyak 72. Untuk data variabel kondisi makroekonomi Indonesia berupa suku bunga acuan BI, nilai tukar rupiah terhadap USD dan inflasi diperoleh dari Statistik Ekonomi dan Keuangan Bank Indonesia tahun 2011-2019. 
Sedangkan data Non-Performing Loan Bank Umum Konvensional diperoleh dari Statistik Perbankan Indonesia (SPI) (Otoritas Jasa Keuangan, 2020).

Populasi yang digunakan adalah seluruh sektor usaha yang dibiayai oleh Bank Umum Konvensional yang terdaftar dan diawasi oleh OJK, yaitu sebanyak 18 sektor usaha. Sedangkan data yang digunakan sebagai sampel dalam penelitian ini adalah sektor usaha yang umum dibiayai oleh Bank Umum Konvensional. Total sampel yang diambil sebanyak 8 sektor usaha.

Penelitian ini menggunakan metode analisis regresi data panel dengan pendekatan random effect model (REM). Pengolahan data menggunakan software E-views 10 untuk mengetahui pengaruh suku bunga acuan BI, nilai tukar rupiah dan inflasi terhadap NPL sektor usaha yang didanai oleh Bank Umum Konvensional di Indonesia serta menarik kesimpulan berdasarkan uji hipotesis yang dilakukan.

HASIL DAN KESIMPULAN

Hasil Uji Signifikansi Partial (uji t)

Tabel 1

Analisis Uji Signifikansi Partial dengan Random Effect Model

\begin{tabular}{ccccc}
\hline Variable & Coefficient & Std. Error & t-Statistic & Prob. \\
\hline C & -17.81341 & 3.405095 & -5.231399 & 0.0000 \\
SB & 0.198005 & 0.531886 & 0.372269 & 0.7109 \\
NILAI_TUKAR & 1.942121 & 0.349052 & 5.563994 & 0.0000 \\
INFLASI & -0.085338 & 0.302779 & -0.281848 & 0.7789 \\
\hline
\end{tabular}
berikut:

Dengan menggunakan Random Effect Model (REM) pada tabel 1 diperoleh hasil sebagai

1. Probabilitas suku bunga acuan BI sebesar 0,7109 ( $p$ value 0,7109 >0,05), maka Ho diterima. Ini mengindikasikan bahwa variabel suku bunga acuan BI tidak berpengaruh secara signifikan terhadap NPL sektor usaha yang dibiayai Bank Umum Konvensional di Indonesia. Hasil penelitian ini mendukung hasil penelitian sebelumnya yang dilakukan oleh Haniifah (2015), Wairimu dan Gitundu (2017), Fajar dan Umanto (2017), serta Naibaho dan Rahayu (2018) yang menyatakan bahwa tingkat suku bunga acuan bank tidak berpengaruh signifikan terhadap NPL. Hal ini terjadi karena kenaikkan suku bunga acuan dilakukan BI secara bertahap dan biasanya kenaikan suku bunga terjadi dalam jangka waktu yang pendek, sehingga tidak terlalu berpengaruh signifikan.

2. Probabilitas nilai tukar sebesar 0,0000 ( $p$ value $0,0000<0,05$ ), maka Ho ditolak. Sehingga dapat disimpulkan bahwa variabel nilai tukar Rp terhadap USD berpengaruh secara signifikan terhadap NPL sektor usaha yang dibiayai Bank Umum Konvensional di Indonesia. Hasil penelitian ini sesuai dengan hipotesis yang ditetapkan, dimana pelemahan nilai tukar Rp terhadap USD akan meningkatkan jumlah kewajiban debitur yang memiliki eksposur kredit dalam valuta asing. Selain itu berdampak pula pada debitur yang memiliki ketergantungan tinggi pada impor bahan baku atau barang jadi, karena harga barangnya akan menjadi lebih mahal. Hasil ini mendukung hasil penelitian sebelumnya yang dilakukan oleh Soebagio (2005), Yulita (2014), Naibaho dan Rahayu (2018).

3. Probabilitas inflasi sebesar 0,7789 ( $p$ value 0,7789 > 0,05), maka Ho diterima. Sehingga dapat disimpulkan bahwa variabel inflasi tidak berpengaruh secara signifikan terhadap NPL sektor usaha yang dibiayai Bank Umum Konvensional di Indonesia. Hasil penelitian ini mendukung hasil penelitian sebelumnya yang dilakukan oleh Nanteza Haniifah (2015) dan Wairimu \& Gitundu (2017) yang menyatakan bahwa tingkat inflasi tidak berpengaruh signifikan terhadap NPL. Hal ini terjadi karena saat inflasi meningkat, maka masyarakat cenderung akan mengurangi pengeluarannya yang bersifat konsumtif, namun tidak mengurangi tanggung jawabnya dalam memenuhi pembayaran kewajiban perbankan. 


\section{Hasil Uji Signifikansi Simultan (uji F)}

\section{Tabel 2}

Analisis Uji Signifikansi Simultan dengan Random Effect Model

\begin{tabular}{cccc}
\hline \multicolumn{4}{c}{ Weighted Statistics } \\
\hline R-squared & 0.388080 & Mean dependent var & 0.154078 \\
Adjusted R-squared & 0.361084 & S.D. dependent var & 0.548425 \\
S.E. of regression & 0.438368 & Sum squared resid & 13.06732 \\
F-statistic & 14.37524 & Durbin-Watson stat & 0.852773 \\
Prob(F-statistic) & 0.000000 & & \\
\hline
\end{tabular}

Berdasarkan tabel 2 di atas terlihat nilai prob. (F-statistic) sebesar 0,000000 ( $p$ value < 0,05), maka Ho ditolak, sehingga variabel suku bunga acuan BI, nilai tukar dan inflasi secara simultan berpengaruh terhadap variabel NPL.

\section{Koefisien Determinasi $\left(\mathbf{R}^{2}\right)$}

Berdasarkan tabel 2 di atas, terlihat nilai adjusted $\mathrm{R}^{2}$ sebesar 0,361084. Hal ini menunjukkan bahwa variabel suku bunga acuan BI, nilai tukar dan inflasi mampu menjelaskan variasi variabel NPL sebesar 36,11\%, sedangkan sisanya sebesar 63,89\% dijelaskan oleh variasi variabel lain yang tidak dimasukkan ke dalam model. Nilai $\mathrm{R}^{2}$ ini terjadi karena adanya variabel signifikan lain yang tidak dimasukkan ke dalam model ini yaitu variabel dari internal bank itu sendiri, seperti kualitas SDM perbankan, kebijakan dan strategi ekspansi kredit, kepatuhan terhadap peraturan perkreditan. Serta variabel eksternal lain seperti peraturan dan kebijakan dari Otoritas Jasa Keuangan (OJK) terkait relaksasi kredit.

\section{DAFTAR PUSTAKA}

Apriyani. (2015). April 2015, NPL melonjak tajam. Infobanknews. http://infobanknews.com/april-2015-npl-kredit-melonjak-tajam/

Fajar, H., \& Umanto. (2017). The impact of macroeconomic and bank-specific factors toward non-performing loan: Evidence from Indonesian public banks. Banks and Bank Systems, 12(1), 67-74. https://doi.org/10.21511/bbs.12(1).2017.08

Haniifah, N. (2015). Economic determinants of non-performing loans (NPLs) in Ugandan commercial banks. Taylor's Business Review, 5(2), 137-153. http://university2.taylors.edu.my/tbr/uploaded/2015_vol5_issue2_p3.pdf

Miskhin, F. S. (2008). Ekonomi uang, perbankan dan pasar keuangan (8th ed.). Salemba Empat.

Naibaho, K., \& Rahayu, S. M. (2018). Pengaruh GDP, inflasi, BI rate, nilai tukar terhadap non performing loan pada bank umum konvensional di Indonesia. Jurnal Administrasi Bisnis (JAB), 62(2), 87-96.

Otoritas Jasa Keuangan. (2020). Statistik Perbankan Indonesia. https://www.ojk.go.id/id/kanal/perbankan/data-dan-statistik/statistik-perbankanindonesia/Default.aspx

Shapiro, A. C. (2016). Multinational financial management. John Wiley \& Sons.

Soebagio, H. (2005). Analisis faktor-faktor yang mempengaruhi terjadinya non performing loan (NPL) pada bank umum komersial (Studi empiris pada sektor perbankan di Indonesia). Universitas Diponegoro.

Wairimu, M. M., \& Gitundu, E. W. (2017). Macroeconomic determinants of non-performing loans in Kenya: 1998-2015. Research Journal of Finance and Accounting, 8(4), 97-105. https://www.iiste.org/Journals/index.php/RJFA/article/view/35707/36721

Wikutuma, A. (2010). Faktor-faktor yang Mempengaruhi non-perfoming Loan Bank Pembangunan Daerah. Universitas Indonesia.

Yudistira, G. (2016). Bank waspadai tren kredit bermasalah. Kontan.Co.Id. https://keuangan.kontan.co.id/news/bank-waspadai-tren-kredit-bermasalah

Yulita, A. (2014). Analisis pengaruh faktor makroekonomi terhadap tingkat kredit bermasalah pada bank umum di Indonesia. Universitas Diponegoro. 